\title{
PENGARUH KRONOFARMAKOLOGI TERHADAP KADAR KOLESTEROL TOTAL DAN TRIGLISERIDA DALAM DARAH PASIEN PENGGUNA OBAT GOLONGAN STATIN DAN FIBRAT
}

\section{EFFECTS OF CHRONOPHARMACOLOGY ON TOTAL CHOLESTEROL LEVELS AND TRIGLYCERIDES IN BLOOD USERS OF MEDICATION I N STATINS AND FIBRATES}

\author{
Resna Sari Asih ${ }^{1}$, Ilham Alifiar ${ }^{2}$, Yedy Purwandy ${ }^{3}$

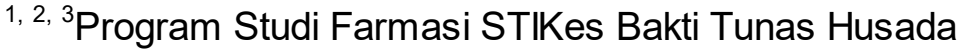 \\ Tasikmalaya, Jawa Barat, Indonesia \\ e-mail : ilhamalifiar@stikes-bth.ac.id
}

\begin{abstract}
Chronopharmacology is a therapy based on circadian rhythms that can be said to be relevant if the risk and symptoms of the disease are predicted to vary over time. This study aims to determine the effect of chronopharmacology on total cholesterol and triglyceride levels in the blood of patients with fibrates and statin groups, so that patients with certain diseases are encouraged to take drugs according to the organ picket hours or circadian rhythms. This study was an observational descriptive study with a cross sectional study design involving 18 patients. Primary data were obtained through interviews and checking total cholesterol and triglyceride levels while secondary data were obtained from the patient's medical record. Based on the results of the analysis using SPSS for statin drug use in the morning and at night getting a value of $P=0.003$. whereas for drug use in the fibrat group in the morning and evening, $P=0.083$ was obtained. Based on the results of the research that has been done, it can be concluded from 18 patients using statins and fibrates in RSUD Dr. Soekardjo Tasikmlaya, for the use of statin drugs at night is more beneficial, but in the use of fibrates in the morning or evening the same effectiveness.
\end{abstract}

Keyword : chronopharmacology, statin, fibrat

\section{ABSTRAK}

Kronofarmakologi adalah terapi berdasarkan ritme sirkadian dapat dikatakan relevan apabila resiko dan gejala penyakit diprediksi dengan bervariasi sepanjang waktu. Penelitian ini bertujuan untuk mengetahui pengaruh kronofarmakologi terhadap kadar kolesterol total dan trigliserida dalam darah pasien pengguna obat golongan fibrat dan golongan statin, agar pasien dengan penderita penyakit tertentu dianjurkan untuk mengkonsumsi obat sesuai jam piket organ atau ritme sirkardian. Penelitian ini merupakan penelitian deskriptif observasional dengan desain penelitian cross sectional dengan melibatkan 18 pasien. Data primer diperoleh melalui wawancara dan pengecekan kadar kolesterol total dan trigliserida sedangkan data sekunder diperoleh dari rekam medik pasien. Berdasarkan hasil analisis dengan menggunakan SPSS untuk penggunaan obat golongan statin pada pagi hari dan 
pada malam hari di dapatkan nilai $P=0.003$. sedangkan untuk penggunaan obat golongan fibrat pada pagi hari dan malam hari didapatkan hasil $P=0.083$. Berdasarkan hasil penelitian yang telah dilakukan, maka dapat disimpulkan dari 18 pasien pengguna obat golongan statin dan golongan fibrat di RSUD dr Soekardjo Tasikmlaya, untuk penggunaan obat golongan statin pada malam hari lebih menguntungkan, akan tetapi pada penggunaan obat golongan fibrat pagi atau malam memberikan efektivitas yang sama.

Kata kunci : kronofarmakologi, statin, fibrat

\section{PENDAHULUAN}

Kronofarmakologi adalah studi tentang bagaimana efek obat bervariasi waktu biologis dan periodik endogen. Seperti diketahui, proses dan fungsi biologis, termasuk fungsi kardiovaskuler (jantung dan pembuluh darah) menunjukkan ritme sirkadian (perubahan aktivitas pada siang-malam, selama 24 jam). Maksudnya, fungsi-fungsi itu mengikuti ritme tubuh secara berulang. Studi epidemiologi menunjukkan bahwa risiko terjadinya angina, infark miokard, dan stroke relatif lebih tinggi pada pagi hari (Anonim, 2009).

Siklus sirkadian adalah proses berputar dari terang ke gelap dan kembali lagi setiap 24 jam, dan kebanyakan spesies yang hidup di permukaan bumi telah beradaptasi dengan perubahan reguler dalam lingkungannya (Foster \& Kritzman, 2004). Irama biologis dari tubuh untuk tidur secara berkelanjutan akan bersinkronasi dengan fungsi tubuh yang lain. Contohnya, perubahan pada suhu tubuh akan berhubungan dengan pola tidur. Pada keadaan normal, suhu tubuh mencapai posisi puncaknya pada sore hari, menurun secara berangsur, dan kemudian menurun secara tajam setelah seseorang tidur (Potter \& Perry, 2010).

Statin merupakan obat penurun kolesterol darah yang menjadi lini pertama dalam terapi dislipidemia dan pencegahan primer serta sekunder penyakit kardiovaskular aterosklerosis ( Desai et al, 2014). Obat ini bekerja dengan menghambat konversi
HMG-CoA menjadi prekursor kolesterol, mevalonate, melalui penghambatan enzim HMG-CoA reduktase (Krawkowski et al, 2011). Berbagai penelitian randomized trial statin secara signifikan dapat menurunkan sekitar $20 \%$ per $\mathrm{mmol} / \mathrm{L}$ penurunan kolesterol LDL (Baigent et al, 2005).

Fibrat adalah golongan obat yang digunakan untuk menurunkan kadar trigliserida juga penurunan LDL yang moderat pada pasien yang kadarnya meningkat dan meningkatkan kolesterol HDL (Alsheikh et al, 2004). Golongan ini menghasilkan penurunan pada LDL (sekitar 10\%), peningkatan HDL (sekitar $10 \%)$ serta menyebabkan penurunan bermakna pada trigliserida plasma (sekitar $30 \%$ ). Fibrat bekerja sebagai ligan untuk reseptor transkripsi nukleus, reseptor alfa peroksisom yang diaktivasi proliferator (PPAR- $\alpha$, peroxisome proliferatoractivated receptor alpha), dan menstimulasi aktivitas lipoprotein lipase. Asam fibrat dapat menyebabkan sindrom seperti miositis. Insidensi miositis meningkat dengan penggunaan bersama inhibitor HMG KoA. Contoh turunan asam fibrat yaitu gemfibrozil dan fenofibrat (Neal, 2005). 


\section{METODE}

Penelitian ini merupakan penelitian deskriptif observasional dengan desain penelitian cross-sectional dimana metode pengambilan data dilakukan secara prospektif dari data sekunder berupa rekam medik pasien hasil laboratorium pada bulan Februari - April 2019 di RSUD dr. Soekardjo Tasikmalaya. Kriteria inklusi dari subjek penelitian

meliputi pasien yang diresepkan obat golongan statin dan golongan fibrat di RSUD dr Soekardjo Tasikmalaya dan pasien yang bersedia menandatangani informed consent. Analisis data yang digunakan yaitu cross-tabulation dan faired sample T-test.

\section{HASIL}

Penelitian ini bertujuan untuk mengetahui pengaruh kronofarmakologi pada pasien pengguna obat golongan statin dan golongan fibrat di RSUD dr.Soekardjo Kota Tasikmalaya periode Februari - April 2019. Subjek penelitian yang memenuhi kriteria inklusi adalah sebanyak 16 orang yang terdiri dari Pasien Laki - laki dan Perempuan dengan berbagai macam Jenis Kelamin, Usia, Alamat, Status pembayaran, Status pendidikan terakhir, Status pekerjaan dan Diagnosa utama.

\begin{tabular}{lcc}
\hline \multicolumn{1}{c}{ Variabel } & $\begin{array}{c}\text { Jumlah } \\
(\mathbf{n}(\%))\end{array}$ \\
\hline Jenis & Laki-laki & $7(38.9 \%)$ \\
Kelamin & & \\
& perempuan & $11(61.1 \%)$ \\
Usia (th) & $30-40$ & $3(16.67 \%)$ \\
& $40-50$ & $3(16.67 \%)$
\end{tabular}

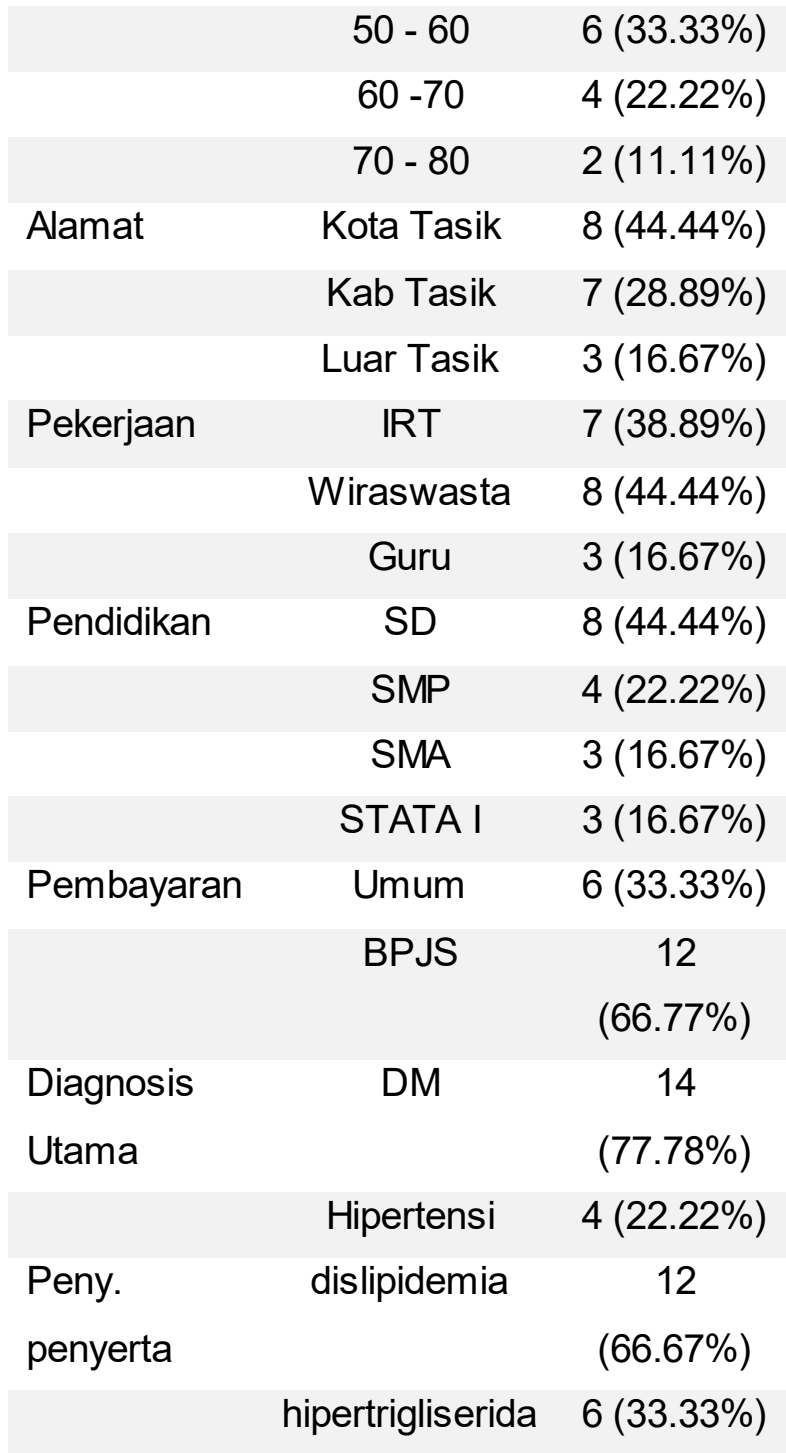

Pada tabel 1 menunjukkan tentang demografi pasien yang menggunakan obat golongan statin dan fibrat lebih banyak dialami oleh perempuan yaitu dengan persentase $62,5 \%$ dibanding laki-laki sebesar $37,5 \%$. Hal ini disebabkan karena perempuan pada penelitian ini mayoritas diatas 50 tahun. Usia diakhir 40 tahun atau 50 tahun merupakan waktu untuk terjadinya menopause normal (Suparni et al, 2016). Ketika perempuan sudah mengalami menopause maka risiko peningkatan kadar kolesterol akan sama dengan laki-laki 
karena estrogen yang semula berperan sebagai pelindung terjadinya aterosklerosis mengalami penurunan (Rayanti et al,2015).

Berdasarkan usia yang paling banyak yaitu pada usia diatas 50 tahun yaitu sebanyak $66,66 \%$. Semakin tua usia seseorang maka fungsi organ tubuhnya semakin menurun, begitu juga dengan penurunan aktivitas reseptor LDL, sehingga bercak perlemakan dalam tubuh semakin meningkat dan menyebabkan kadar kolesterol total lebih tinggi, sedangkan kolesterol HDL relative tidak berubah (Bachri, 2004).

Berdasarkan hasil demografi status alamat pasien pengguna obat golongan statin dan fibrat paling banyak terdapat 8 orang $(44,44 \%)$ pasien terdapat di wilayah Kota Tasikmalaya, terdapat 7 orang $(28,89 \%)$ pasien terdapat di wilayah Kabupaten Tasikmalaya dan sebanyak 3 orang $(16,67 \%)$ terdapat di luar Tasikmalaya.

Berdasarkan data rekam medik dan wawancara terhadap pasien pengguna obat golongan statin dan fibrat paling banyak adalah seseorang yang memiliki pekerjaan. Hasil karakteristik pekerjaan menunjukkan $61,11 \%$ responden bekerja. Jenis pekerjaan dapat memicu timbulnya penyakit melalui ada tidaknya aktivitas fisik didalam pekerjaan, sehingga dapat dikatakan pekerjaan seseorang mempengeruhi tingkat aktivitas fisiknya (Notoadmojo, 2011). Hasil penelitian yang relevan lainnya menunjukkan bahwa pada umur yang lebih tua dampak penurunan kualitas hidup akan lebih dirasakan dibandingkan dengan umur yang lebih muda (Riviere et al, 2015).

Berdasarkan demografi pasien berdasarkan hasil demografi status tingkat pendidikan pasien paling banyak terdapat $8(44,44 \%)$ pasien dengan tingkat pendidikan Sekolah Dasar, 4 orang $(22,22 \%)$ pasien dengan tingkat pendidikan Sekolah Menengah Pertama (SMP), 3 orang $(16,67 \%)$ pasien dengan tingkat pendidikan Sekolah Menengah Atas (SMA) dan 3 orang $(16,67 \%)$ pasien dengan tingkat Pendidikan Strata I (S1). Hal ini terkait dengan semakin tinggi tingkat pendidikan seseorang maka dia akan cenderung untuk berperilaku positif karena pendidikan yang diperoleh dapat menjadi dasar pemahaman seseorang terhadap kebutuhan akan informasi terkait self management pasien dan perilaku mencari pelayanan kesehatan yang tepat (Akhmad, et al 2016). Meningkatnya tingkat pendidikan akan meningkatkan kesadaran untuk hidup sehat dan memperhatikan gaya hidup dan pola makan (Notoadmodjo, 2011).

Berdasarkan demografi pasien pengguna obat golonga statin dan fibrat pada status pembayaran pasien, pembayaran dengan asuransi Badan Penyelenggara Jaminan Kesehatan (BPJS) merupakan pembayaran terbanyak yaitu sebesar $66,77 \%$. berdasarkan diagnosis utama pasien yang mengalami penyakit diabetes melitus sebanyak $77,78 \%$ sedangkan pasien yang mengalami hipertensi sebesar 22,22\%. Diabetes merupakan faktor resiko utama terjadinya penyakit pembuluh darah. Gula darah yang tidak terkendali merusak endotel. Resistensi insulin juga berkaitan dengan kenaikan tekanan darah, kolesterol, trigliserida, inflamasi, kekentalan darah, dan lain-lain (Tandra, 2018). Hiperglikemia sering disertai dengan timbulnya sindrom metabolik yaitu hipertensi, dyslipidemia, obesitas, disfungsi endotel dan faktor protrombotik yang kesemuanya itu akan memicu dan memperberat komplikasi kardiovaskuler (Cheng et al., 2012). Diabetes dapat terjadi karena perubahan kadar gula darah, gula darah yang tinggi akan menempel pada dinding pembuluh darah yang menimbulkan AGEs. Adavanced Glycosylated Endproducts 
(AGEs) merupakan zat yang dibentuk dari kelebihan gula dan protein yang saling berikatan. Keadaan ini merusak dinding bagian dalam dari pembuluh darah, dan menarik lemah yang jenuh atau kolesterol menempel pada pembuluh darah, sehingga reaksi inflamasi terjadi. Sel darah putih (leukosit) dan sel pembekuan darah (trombosit) serta bahan-bahan lain ikut menyatu menjadi satu bekuan plak (plaque), yang membuat dinding pembuluh darah menjadi keras, kaku dan akhirnya timbul penyumbatan yang mengakibatkan perubahan tekanan darah yang dinamakan hipertensi (Tandra, 2009).

Berdasarkan data demografi penyakit penyerta dari data rekam medik, pasien pengguna obat golongan statin dan fibrat berdasarkan penyakit penyerta terdapat pasien dengan penyakit penyerta yaitu dislipidemia sebanyak 12 orang $(66,67 \%)$ dan hipertrigliserida sebanyak 6 orang $(33,33 \%)$. kehadiran dislipidemia meningkatkan risiko terjadinya hipertensi. Kadar total kolesterol serum meningkat sesuai dengan peningkatan tekanan darah. Konsentrasi serum pada penderita hipertensi lebih tinggi dari pada serum normotensif mengindikasikan risiko komplikasi kardiovaskuler dan cerebrovaskuler yang lebih besar seperti penyakit jantung koroner dan stroke pada pasien hipertensi dengan kadar kolesterol tinggi (Akuyam S et al, 2009).

\section{KRONOFARMAKOLOGI}

\begin{tabular}{|c|l|c|c|}
\hline \multirow{4}{*}{ No } & \multirow{3}{*}{ waktu } & \multicolumn{2}{|c|}{$\sum$ pengguna } \\
\cline { 3 - 4 } & & $\begin{array}{c}\sum \text { Statin (P } \\
\text { 0.003) }\end{array}$ & $\begin{array}{c}\sum \\
\text { Fibrat } \\
(\boldsymbol{P}= \\
\end{array}$ \\
& & & $\mathbf{0 . 2 8 5 )}$ \\
\hline 1 & Pagi & 6 & 3 \\
\hline 2 & Malam & 6 & 3 \\
\hline
\end{tabular}

Pada penggunaan obat golongan statin dan golongan fibrat berdasarkan waktu penggunaan dilakukan uji paired sample Ttest hari dan malam hari, dapat antara penggunaan pagi dapat dilihat hasil yang dilakukan untuk melihat adakah pengaruh antara keduanya. Berdasarkan hasil analisis paired sample T-test untuk penggunaan obat golongan statin pada pagi hari dan pada malam hari didapatkan dimana nilai $P$ 0,003 , sebelumnya pada pengambilan keputusan berdasarkan nilai $P$ yaitu jika nilai $P<0,05$, maka $\mathrm{HO}$ ditolak dan $\mathrm{Ha}$ diterima sedangkan jika nilai $P>0,005$, maka $\mathrm{HO}$ diterima dan $\mathrm{Ha}$ ditolak. Berdasarkan output diketahui bahwa $P$ adalah sebesar 0,003 . Karena nilai $P 0,003$ $<0,05$ menunjukan adanya pengaruh yang signifikan kronofarmakologi terhadap kadar kolesterol total penggunaan obat golongan statin. Dan hasil untuk penggunaan obat golongan fibrat pada pagi hari dan malam hari didapatkan hasi yaitu $P=0,083>0,05$ menunjukan tidak adanya pengaruh yang signifikan kronofarmakologi terhadap kadar trigliserida penggunaan obat golongan fibrat. 


\section{SIMPULAN}

Berdasarkan hasil penelitian yang telah dilakukan, maka dapat disimpulkan dari 18 pasien pengguna obat golongan statin dan golongan fibrat di RSUD dr Soekardjo Tasikmlaya, untuk penggunaan obat golongan statin pada malam hari lebih menguntungkan, akan tetapi pada penggunaan obat golongan fibrat pagi atau malam memberika efektivitas yang sama

\section{DAFTAR PUSTAKA}

1. Akuyam S, Aghogho U, Aliyu, Bakari Hypertensive Northern Nigerians, Int J of Med and Med Sci. (2009). 73-74

2. Alsheikh-Ali AA, Abjourjaily HM, Stanek E. (2004). increases in HDL-cholesterol are the strongest predictors of risk reduction in lipid intervention trials. Circulation.110(suppl III):813

3. Anonim.(2018).https://zulliesikawati.wor dpress.com/2009/02/05/kronoterapidan-kronofarmakologi-untuk-obatkardiovaskulerl. [Diakses tanggal 7 Maret 2019]

4. Baigent, et al. (2005). Efficacy and safety of cholesterol lowering treatment: prospective meta-analysis of data from 90,056 participant in 14 randomised trials of statins. Lancet.

5. Cheng, T. R., Tarsia, J., Aysenne, A., Boehme, A. K., Sartor, A. E., MartinSchild, S. (2012) Elevated Plasma Factor VIII in Patients with Ischemic Stroke: Does it have any Association with Hypertensive Heart Disease? Jounal Of Neurological Disorders \& Stroke. 1027.
6. Desai, et al. (2014). Non-Cardiavascular effects associated with statins. British Medical Journal. 30-37

7. Krawkowski, M. and Czobor, P.(2011). Cholesterol and cognition in schizophrenia: A Double-blind study of patiesnt randomized to clozapine, olanzapine and haloperidol. 27-33

8. Perry, Anne G., Patricia A. potter. (2005). Buku Ajar Fundamental Keperawatan Konsep dan Praktik. Edisi 4. Jakarta: EGC

9. Tandra, Hans. (2018). Dari Diabetes Menuju Jantung dan Stroke. Jakarta. PT Gramedia Pustaka Utama. P30 
